Przekota, G., Szczepańska-Przekota, A., Mentel, G., Mentel, U., \& Snieška, V.

(2020). Causality of the relationship between wheat prices and economic

conditions - an evidence for sustainable development. Journal of International

Studies, 13(3), 161-179. doi:10.14254/2071-8330.2020/13-3/11

\title{
Causality of the relationship between wheat prices and economic conditions - an evidence for sustainable development
}

\section{Grzegorz Przekota}

Department of Economics, Faculty of Economic Sciences,

Koszalin University of Technology,

Poland

grzegorzprzekota@,wp.pl

ORCID 0000-0002-9173-2658

\author{
Anna Szczepańska-Przekota \\ Department of Finance, Faculty of Economic Sciences, \\ Koszalin University of Technology, \\ Poland \\ anna.szczepanska-przekota@,tu.koszalin.pl \\ ORCID 0000-0002-4002-5072
}

\section{Grzegorz Mentel}

Department of Quantitative Methods, Faculty of Management,

Rzeszow University of Technology,

Poland

gmentel@prz.edu.pl

ORCID 0000-0002-6371-1219

\section{Urszula Mentel}

Department of Security Science, Faculty of Management,

Rzeszow University of Technology,

Poland

u.mentel@prz.edu.pl

ORCID 0000-0003-2060-8980

\section{Vytautas Snieška}

Kaunas University of Technology,

Lithuania

vytautas.snieska@,k.tu.lt

ORCID 0000-0001-8777-273X 
Abstract. In the recent years agriculture as a branch of economy has been the subject of large transformations. Agricultural holdings have played a very important role for the sustainable socio-economic development. Agriculture is becoming more modern but its contribution to GDP is decreasing. The question as to the connection between the condition of the agricultural market and economy-wide conditions and sustainable development seems to be fundamental. This is the objective of this paper. Based on wheat prices and in the US, the UK, France and Poland in the years 2000-2018, the connection between these variables was determined. The tests for causality were carried, and the auto-regression VAR model was built. The general conclusions are consistent. It is evident that economy-wide conditions indeed depend on the prices of agricultural produce from the previous periods. High prices for agricultural produce and, in particular those of wheat, weaken future economic conditions. This conclusion for Poland and France is strong, while it is weaker for the UK and the US.

Keywords: agriculture, wheat prices, GDP, causality, sustainable development.

JEL Classification: O11, O57, E32, Q11

\section{INTRODUCTION}

Changes that are occurring in economic activities over time are the subject of interest for many economists. One of the primary goals of economics is to understand their causes. Nowadays, there is a prevailing view that economy is subject to certain fluctuations, that is disturbances in the long-term growth, which develop at irregular intervals and which are of an irregular force, and cause changes in the functioning of the entire economy (Romer, 1996). Fluctuations on agricultural markets may take place in fashion similar to the fluctuations in the entire economy. The essence of the agricultural and, more broadly, food market is manifested in the fact that it is responsible for satisfying basic human needs, which is of strategic importance. Therefore, much attention is paid to these markets not only in the economic growth but also in the political sphere. Therefore, the question concerning causal relationship between the economic situation of a state and the economic conditions on the agricultural market seems to be a logical one. Since agricultural markets constitute a significant part of economy, those risk factors that influence the agricultural markets have the impact on entire economy. The main concern is determination of the direction and the force behind the variability transfer. A reciprocal direction of the dependence can be justified quite easily as, on the one hand, good conditions on agricultural markets mean an increase of production profitability, and this may be an impulse for the global production growth; and on the other one, a global growth of incomes may contribute to the increasing demand for agricultural produce and thereby to the improved conditions in this market. The links between a relatively small but strategic sector and the economy as a whole are of particular interest. Comparative research between different countries can provide valuable insights in economic knowledge and economic policy. The position of agriculture within the economy seems more important in developing countries than in the developed ones.

The research indicates that the industrial model with the metaphor of "cheap and abundant food" ravaged the natural environment, degrading ecosystems at the same time. Thus, a fundamental challenge to agriculture appeared, which also applies to agricultural holdings, i.e.: an increasing agricultural production without increasing environmental pressure using the concept of sustainable development (GOS, 2011). Creating a sustainable agricultural development path means an improvement of the quality of life in rural 
areas, ensuring enough food for present and future generations and generation sufficient income for farmers (Udemezue \& Osegbue, 2018).

As dependencies between the agricultural market and economic conditions is reciprocal, diagnosing the statistical properties of this process looks interesting. Thereby, the purpose of the present study is to examine the force and the direction of the dependencies between wheat prices in the United States, the United Kingdom, France and Poland and the Gross Domestic Product in these countries. The countries represent varying degrees of economic development as well as different types of farms. The United States appears here as the world leader, while Great Britain and France are important for the European economy. In turn, although Poland is a considerable country, it is a recipient of world prices. There is not even an agricultural commodity futures exchange in Poland, and the grain purchase system is based on forward contracts. Nowadays, much is said about the tertiarization of the economy. Meanwhile, the United States is a good example of the sustainable development of agriculture, industry and the service sector. Special attention has been paid here to the assessment of causality in the relationship between the wheat prices and GDP. Data fom the years 2000-2017 were analysed. In the United States (CBOT), the United Kingdom (LIFFE) and France (MATIF), the prices of futures contracts from these markets were accepted as wheat prices, while in Poland purchasing prices were the subject of an analysis.

\section{THE ROLE OF AGRICULTURE IN SUSTAINABLE ECONOMIC DEVELOPMENT}

The review of the theory about the role of agriculture in economic development shows that there are two opposite views about the central role of agriculture in the process of economic growth (Tsakok \& Gardner, 2007). These are the linear-stages theories and structural change models. One notes that agricultural development is essential for overall economic transformation of a country, others note that economies can invest to build an industrial base and bypass the process of agricultural development (Johnston, 1970).

The linear-stages theory is a theory of economic development where it a country passes through sequential stages to achieve development (Fisher, 1935; Clark, 1940; Rostow, 1960, Ruttan, 1965). According to the Fisher-Clark's theory economic growth is achieved by increases of output per worker in any sector or by the transfer of labour from sectors with low output per worker to sectors with higher output per worker. Agriculture is treated as part of traditional economy. In the modern economy agriculture has a very small share in economics growth. An increase in agricultural productivity is important in the transition process from traditional to modern economy. It provides a mass market for the products of the emerging industrial sectors and generates the capital investment for new leading sectors outside the agriculture (Johnston, 1970). Food sustainability means that systems should be developed to ensure that the world's current and future population can access safe, nutritious, and sufficient food (Sánchez García et al., 2019).

Lewis' two-sector surplus model is a popular model of structural change (Lewis, 1954). Lewis shows why industrial and agrarian revolutions go always together and why economies where agriculture is stagnant do not show industrial development. A key implication of this model is that a growth in agricultural productivity is central to development (Todaro \& Smith, 2011; Kocisova et al., 2018). The level and pace of economic development translate into the scope of the broadly understood progress and innovations implementation. Progress in the technical, technological, or biological scope, as well as various innovations (i.a. technical and organizational), which, by design, are to introduce favourable changes in economic activities, may also facilitate achieving sustainability in agriculture. For instance, sustainable intensification is a positive example of the use of natural processes in agricultural activity (Tittonell, 2014). Spatial modelling describes the impact of regional economic factors on agricultural export competitiveness. Dispersion of 
developing markets with higher export competitiveness may be more prevalent in lower-proportioned clusters (Huo et al., 2019).

Nowadays conditions of a social nature stimulate agricultural holdings to focus on sustainable development. An increase of society's awareness with regards to environmental goods and nutritional qualities of foodstuffs directly translates into a growth of demand for local and regional produce, and a growing interest in direct cooperation with an agricultural producer (Bilan et al., 2018). Institutional conditions are an equally important element of sustainable agricultural development. Spreading of sustainable agricultural practices over the farm requires the implementation of multilateral institutional activities to correct the undesirable effects of agricultural activity, or even prevent them outright. In both cases the corporate and the public space, agriculture discussions are increasingly oriented toward ecological approaches and sustainable development that recognize the limits imposed by natural resources and toward improved social outcomes (UNEP, 2011).

The decreasing importance of agriculture is manifested by the possibility of a substantial expansion of agricultural production with a constant or declining farm labour force. As economic growth proceeds, agriculture declines in economic importance relative to manufacturing and services (Martin \& Warr, 1990). Unfavourable price relations - price scissors - of agricultural products and means of production may lead to difficulties related to environmental and social sustainability. Thus, if we look at agriculture more widely, it turns out that many sectors of industry and services are closely related to agriculture. This can be called agribusiness, which is the combination of all the inputs and outputs of agriculture. Combined, they represent much bigger shares of the economy than just only the primary sector (Pryor \& Holt, 1999).

\section{SUPPLY-DEMAND CONDITIONS OF PRICE LEVELS IN AGRICULTURE}

In agricultural markets, the demand exhibits a greater stability than the supply, which is natural, and it is the result of the nature of agricultural production. Prices regulate the market, yet this mechanism may be disturbed on the part of institutions. On the demand side, the most important factors which have the impact on the prices of agricultural produce are connected with an increase of population of people, an economic growth and changes of models in the developed countries in the direction of high-quality agricultural produce (Rezitis \& Sassi, 2013). Those factors may be perceived as the main reason for increased food prices, as well as variability, especially when there are no reserves (Prakash, 2011; Ivashkiv, 2019; Morkūnas et al., 2019; Sánchez-López et al., 2019). The Gross Domestic Product is responsible for a considerable part of the total movements of agricultural prices in the years 1971-2008 (Gilbert, 2010).

On the supply side of agricultural products there are accepted several main factors which are responsible for changes in prices: extreme weather phenomena, a slowdown in the increase of the production of cereals, the availability of resources and the increase in oil prices as a factor of production costs growth (Keatinge, 2015; Algieri, 2014). A variation of agricultural factor endowments between EU regions results in technological efficiency disparities in agricultural holdings of different kinds of production. The combination of demand and supply factors allows a better description of price formation and forecasting (Borensztein \& Reinhart, 1994). This is important since it shows the problem of links between the economic situation of the agricultural sector and the general economic situation. Therefore, factor endowments play an important role in the transformation of production factors into effects (Guth \& Smędzik-Ambroży, 2019).

Taking the first factor related to the supply into consideration, i.e. extreme weather phenomena, it can be observed that they are responsible for the limitations of agricultural produce deliveries to many regions of the world. What is more, it is expected that such situations may repeat more and more frequently in the future. For instance, the Australian drought in the years of 2006 and 2008 caused that wheat crops decreased 
in this country by ca. 50\%. In 2010, droughts in Russia, Ukraine and in Kazakhstan caused a reduction of wheat production by $27 \%, 19 \%$ and $35 \%$, respectively. Although other studies indicate that such single cases of drought spread over time and cannot constitute a reason of a sharp increase of prices on the global scale, as each of these countries accounts for a small part of the world production only, and similar disasters occur practically in a continuous manner, and they had been earlier included in the world price (Lagi et al., 2011). There are two strategies for governments to promote territorial institutional exaptation. Firstly, they should facilitate contact and meeting spaces between the various actors to enable their ability to increase (adapt) and dramatically (exapt) innovate. Secondly, the use of such institutional interfaces as a vehicle for its general policy (supply perspective) should be improved, but also the role of catalyst and accelerator of certain market changes (demand prospects) should be more disruptive (Gallego-Bono \& Chaves-Avila, 2019; Termosa, 2017).

Taking the second factor into consideration, i.e. a slower pace of the increase of agricultural production, it is estimated that in the years 1970-1990 the world production of cereals grew on average by $2.2 \%$ annually with an average increase of population numbers by 1.7\% p.a. However, in the years of 1990-2007 the pace of an increase of the total world production of cereals declined to the average level of $1.3 \%$ annually, while the pace of the increase of population numbers also declined, but only to the average level of $1.4 \%$ p.a. (Trostle, 2008). The slower growth of the production of cereals starting from the year 2000 with decisions concerning a limitation of reserves in the leading developed countries contributed to a decrease of cereals stocks. For example, the percentage of stocks compared to consumption for three main agricultural raw materials (wheat, corn and soya) at the end of the season declined from over 34\% in the year 1990 to nearly $18 \%$ in the year 2007 (Wiggins, 2010).

\section{METHOD OF ANALYSIS}

The primary research related to the connection of agricultural market with economic activity was based on the correlation coefficient. An essential issue concerning apparent correlations is connected with this relatively simple method. The variables may be connected by the way of a correlation, but there is no need to be any cause and effect relationship between them. Using the tests of stationarity and cointegration, any possible existence of an apparent correlation can be verified (Engle \& Granger, 1987). An approach based on VAR type vector and autoregression models are other approaches to the issue of the connection and modelling of dependences (Sims, 1980). The model in its output form can be written as:

$$
Y_{t}=A_{0} D_{t}+A_{1} Y_{t-1}+A_{2} Y_{t-2}+\ldots+A_{k} Y_{t-k}+e_{t}
$$

where:

$Y_{t}=\left[Y_{1 t}, Y_{2 t}, \ldots, Y_{k t}\right]^{\prime}-$ vector of the observations of the current variable values,

$D_{t}-$ vector of the deterministic variables of the model (e.g. a deterministic trend, deterministic seasonality, an average of the process),

$A_{0}$ - matrix of those parameters that appear with non-stochastic variables,

$A_{i}$ - matrices of parameters with the delayed variables of vector $Y_{t}$,

$e_{t}=\left[e_{1 t}, e_{2 t}, \ldots, e_{k t}\right]-$ vector of stationary random disruptions.

The model in its output form is a classical construction. It requires a selection of a group of variables that belong to vector $Y_{t}$ and an establishment of the order of delay $k$ for them. The variables used should be stationary (Phillips, 1986).

In the study, the Wiener-Granger definition of causality was accepted: $X$ is the cause (in Granger's sense) of $Y$, it is described as $X \rightarrow Y$ if the current values $Y$ can be forecast with a greater precision using the future values $X$ than without their use, the remaining information being unchanged (Granger, 1969). The definition of causality points to a certain statistical process of the formation of the variables values and it is 
not equivalent to the causal factor, yet it permits one to assess whether the forecasts of the independent variable $(X$ or $Y)$ can be corrected by the observations of the values of the independent variable $(Y$ or $X)$. A VAR model in an output form may be used in an examination of the causality of variable and in forecasts. Nevertheless, an interpretation of the impulse response function may be more important. This tool requires adequate transformations of the elementary model to a structural model (Enders, 2004). A structural VAR model can be written as follows:

$$
B Y_{t}=\Gamma_{0} D_{t}+\Gamma_{1} Y_{t-1}+\Gamma_{2} Y_{t-2}+\ldots+\Gamma_{k} Y_{t-k}+\xi_{t},
$$

where:

$Y_{t}=\left[Y_{1 t}, Y_{2 t}, \ldots, Y_{k t}\right]^{\prime}-$ vector of the observations of current variable values,

$D_{t}$ - vector of the deterministic variables of the model,

$\Gamma_{0}$ - matrix of parameters with the variables of Dt vector,

$B$ - matrix of parameters with variables of $Y_{t}$ vector without any lag,

$\Gamma_{i}$ - matrix of parameters with $Y_{t}$ variables with lag,

$\xi_{t}$ - vector of the random disturbances of the structural model.

The following relationships occur between the primary and structural forms:

$$
\begin{aligned}
& A_{0}=B^{-1} \Gamma_{0} ; \\
& A_{i}=B^{-1} \Gamma_{i} ; \\
& e_{t}=B^{-1} \xi_{t} .
\end{aligned}
$$

The impulse response function permits an evaluation of the reaction of a single variable to a unit variation of other variables included in the multi-dimensional system. What is required here is a representation of the process in the form of a moving average:

$$
Y_{t}=\mu+\sum_{i=0}^{\infty} \theta_{i} \xi_{t-i}
$$

where $\theta_{i}=\Phi_{i} B^{-1}$, a $\xi_{t}$ is white noise with variance and covariance matrices. Matrix elements $\theta_{i}$ include responses of the systems to individual disturbances. Element $\theta_{j k, i}$ describes the reaction of the $j$ th variable to the individual disturbances of $k$ variable that occurred $i$ periods before. Owing to an update by $i$ periods, $\theta_{j k, i}$ describes the reaction of the $j^{\text {th }}$ variable in the $i^{\text {th }}$ period forwards to the current individual disturbance of $k$ variable.

The formula presented above makes it possible to forecast the future states of the system. The forecast of variables for $n$ periods forwards is as follows:

and the forecast error:

$$
Y_{t+n}=\mu+\sum_{i=0}^{\infty} \theta_{i} \xi_{t+n-i}
$$

$$
Y_{t+n}-E_{t} Y_{t+n}=\sum_{i=0}^{n-1} \theta_{i} \xi_{t+n-i} .
$$

Series of annual data are subject to modeling. The data period lasts 18 years, this is a short period and there may be problems with the reliability of the applications (Toda \& Phillips, 1993). Therefore, the conclusions must be drawn with a lot of attention. The series length problem can be solved in several ways:

1. Time series can be extended. However, there is a problem of structural changes in the economy that particularly affected Poland, but also other countries. Older data may not be comparable with the new ones.

2. Increase the frequency. This can be done for quarterly data, then we would have 72 observations, but the agricultural production cycle is annual, especially the crop production, and animal production depends on crop production therefore this may not matter. 
3. Perform data analysis on the first differences. And so it was done here. Therefore, initially the levels of variables for trend assessment were presented, but the first differences were examined in the relationship study.

\section{DATA SUBJECT TO ANALYSIS}

The data related to wheat prices are presented in Figure 1. These are monthly data. This is the frequency of recording purchase prices in Poland, which is why other data has been adjusted accordingly. Over the period examined, three clear cases of peak quotations can be observed. They occurred at the beginning of the year 2008, in the first half of the year 2011 and at the end of the year 2012. Apart from this, there was a price rise in the year 2004; the last year saw price increases, as well. Intensified variability periods correspond to peak quotations, which can be seen in the diagram of quotation increments. In Western exchanges, intensified variability periods occurred in the years 2007-2009 and 2011-2013. In Poland, this was additionally the end of the year 2003 and the entire 2004.
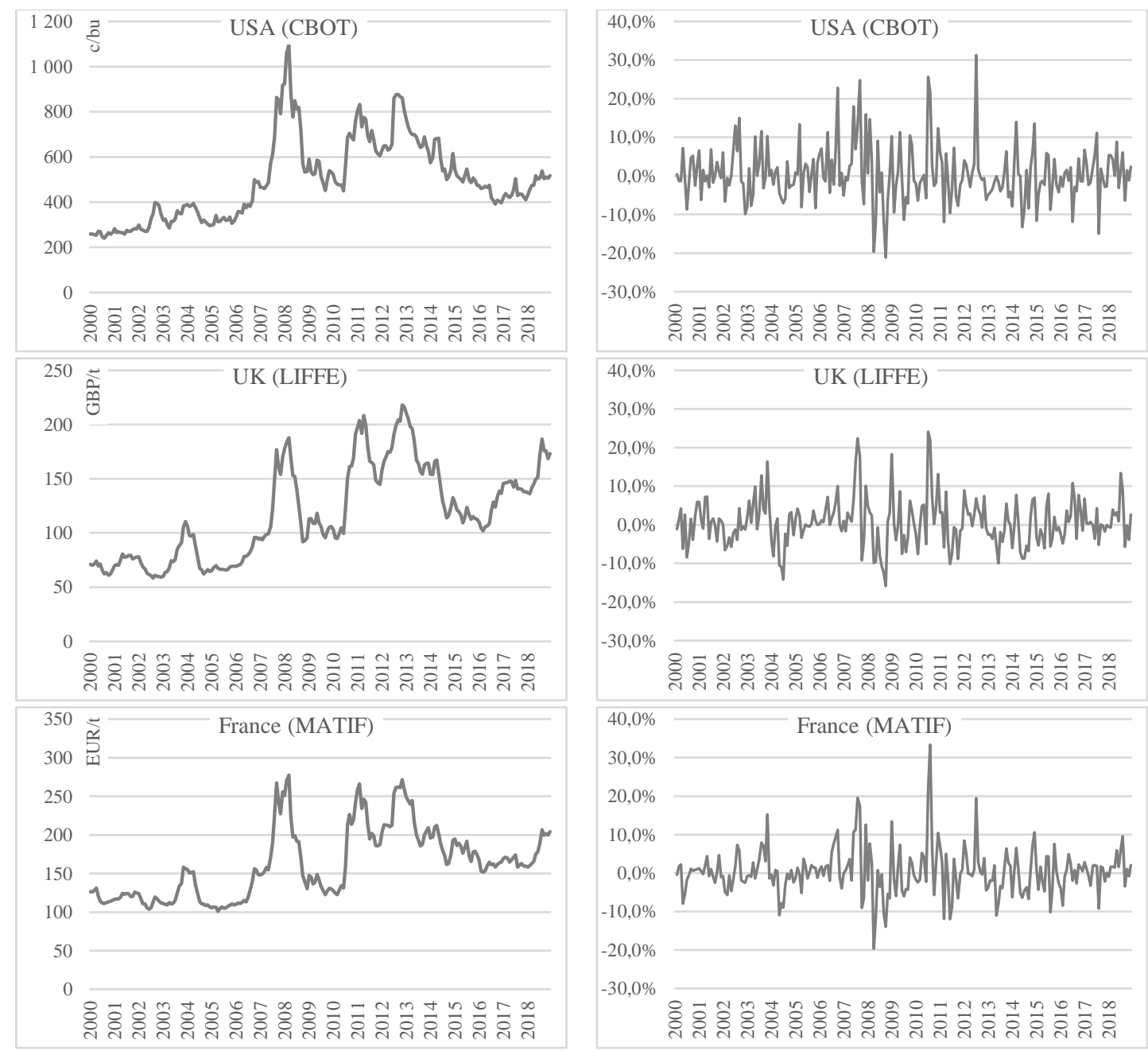

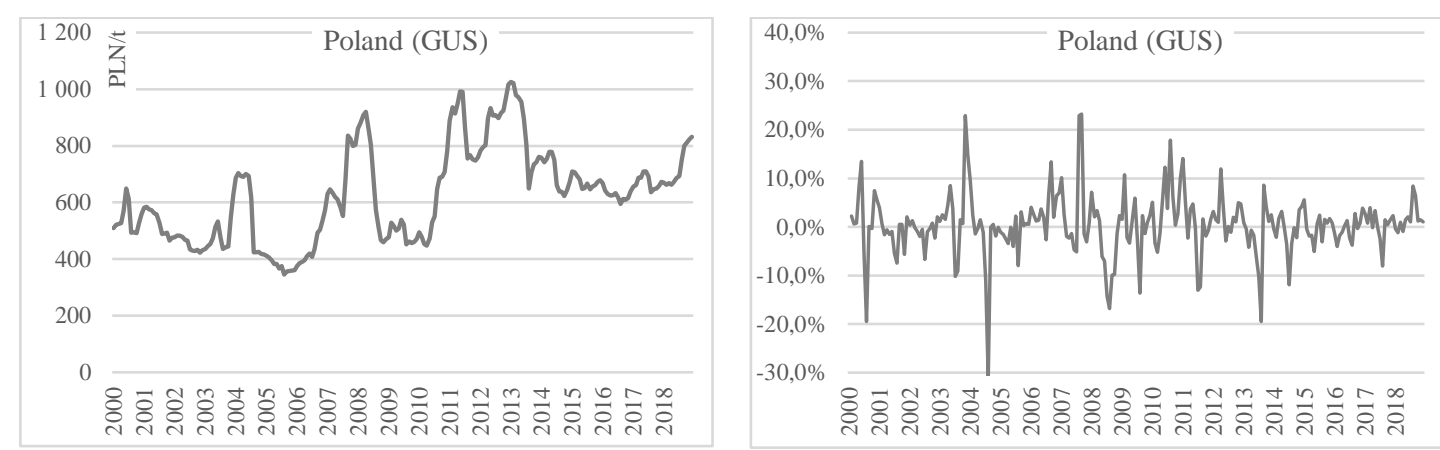

Figure 1. Prices and variability of the prices of wheat in the years 2000-2018 (monthly data). Source: Authors' own work based on the data from CBOT, LIFFE, MATIF and GUS.

Similarities between the time series analyzed are disclosed in the correlation coefficients determined (Table 1). This examination does not take into account any exchange rate changes. In spite of this, it may be stated that quotations in all the markets are characterized over a long period of time by consistent directions. In this perspective, the situation of short-term variations looks different. Indeed, positive values of correlation coefficients were obtained. They are relatively high even for the CBOT, LIFFE and MATIF exchanges, yet they are low for Poland. Short-term variations in the Polish market differ from short-term variations in Western exchanges, even though long-term trends are consistent.

Table 1

Correlations of logarithm wheat quotations

\begin{tabular}{|c|c|c|c|c|}
\hline & CBOT & LIFFE & MATIF & POLAND \\
\hline CBOT & & 0.8753 & 0.8964 & 0.7291 \\
\hline LIFFE & 0.6607 & & 0.9537 & 0.8797 \\
\hline MATIF & 0.7667 & 0.8295 & & 0.9065 \\
\hline POLAND & 0.2690 & 0.4417 & 0.3619 & \\
\hline
\end{tabular}

Explanations: above the diagonal: correlations for levels; below the diagonal: correlations for increments. Source: Authors' own calculations

Figure 2 presents the level and the increments of the values of the Gross Domestic Product. The data presented is the real data. GDP is presented in the national currency according to prices from the year 2010. Over the period covered by the examination, there was one large crisis in the United States, United Kingdom and France. In these three economies, the year 2009 saw the largest absolute drop of GDP. In the entire period Poland obtained the largest GDP increment with an annual average of 3.7\%; for the United States this was $1.9 \%$, for Great Britain: $1.8 \%$ and for France: $1.2 \%$ annual average. A good situation in the economic development of Poland is evident in particular in the diagram of GDP increments. 

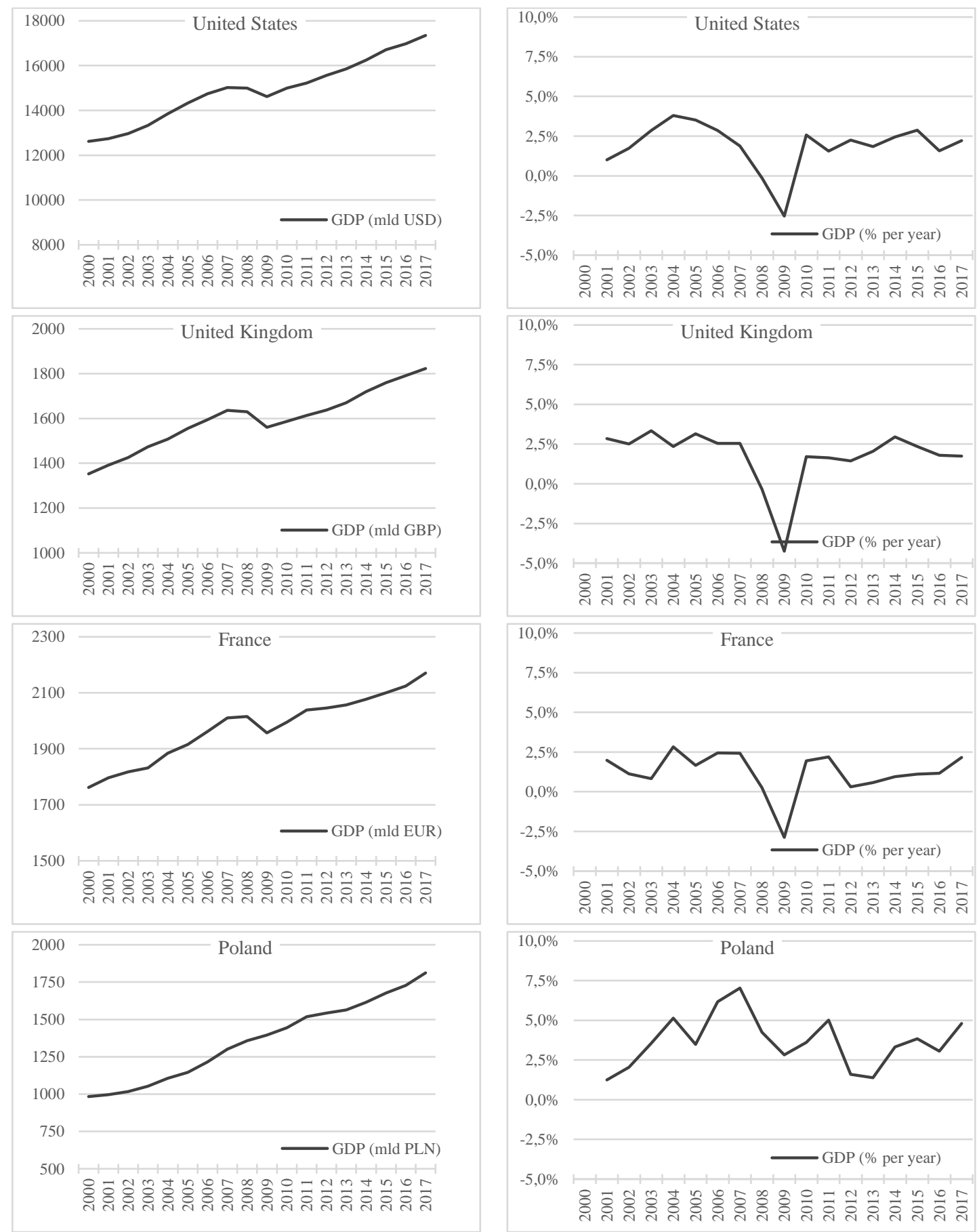

Figure 2. GDP as an economic activity index in the years 2000-2017.

Source: Authors' own work based on the data from the United Nations Statistics Division.

The correlation factors (cf. Table 2) may prove a strong connection between the economies of the United States, United Kingdom and France. Poland stands out here: indeed, long-term behavior is similar to that of Western economies (high values of correlation coefficients for the levels), yet in a short-term perspective, the Polish economy behaves more independently (low values of correlation coefficients for the increments). 
Correlations of logarithm values of the Gross Domestic Product

\begin{tabular}{|c|c|c|c|c|}
\hline & $\begin{array}{c}\text { The United } \\
\text { States }\end{array}$ & $\begin{array}{c}\text { The United } \\
\text { Kingdom }\end{array}$ & France & Poland \\
\hline The United States & & 0.9918 & 0.9902 & 0.9729 \\
\hline The United Kingdom & 0.8781 & & 0.9844 & 0.9443 \\
\hline France & 0.7732 & 0.8039 & & 0.9749 \\
\hline Poland & 0.2372 & 0.0993 & 0.4715 & \\
\hline
\end{tabular}

Explanations: above the diagonal: correlations for levels; below the diagonal: correlations for increments.

Source: Authors' own calculations

The data related to the Gross Domestic Product are the ones with annual frequency, whereas the wheat prices reflect the data with monthly frequency. Hence, an examination of the connection of wheat prices with the Gross Domestic Product requires an appropriate data transformation. For this reason, further investigations were based on average annual prices.

\section{RELATIONSHIP BETWEEN WHEAT PRICES AND ECONOMIC CONDITIONS}

The data presented in Figure 1 and Figure 2 clearly show a trend in the levels of the variables analyzed. This trend constitutes the basic reason for the non-stationarity of economic time series. For this reason, an analysis of relationships between the levels of variables may characterize an apparent dependence. A simple operation that may be conducted in this situation is to use the increments of the stationary variables. In connection with the above, further modeling of the dependences of wheat prices and economic conditions measured by GDP was conducted on the logarithm increment levels of these variables, which consists in an assessment of the modelling of relative increments.

Table 3 presents a correlative connection of the increments of wheat prices and economic activity. It becomes evident that a positive connection was obtained here, i.e. a compliance in the direction of changes in wheat prices and economic activity. This relationship proves to be the strongest in France $(r=0.6760)$, similarly in Poland $(\mathrm{r}=0.5977)$; it is weaker yet also positive in the USA and the United Kingdom $(\mathrm{r}=0.2789$ and $r=0.2674$, respectively). It follows from the above that good economic conditions are related to larger wheat price increments, and poorer economic conditions are related to decreasing wheat prices. The situation is not obvious and such a simple conclusion may be misleading as economic conditions are the result of what took place in the previous periods. Thus, without examining the impact of the past, an examination based on the correlation factor may be misleading. The use of VAR type models offers a solution in this situation.

Table 3

Relationships of wheat prices with economic conditions

\begin{tabular}{|c|c|c|c|c|}
\hline Wheat & GDP & Correlation & \multicolumn{2}{|c|}{ Causality } \\
\hline $\mathrm{X}$ & $\mathrm{Y}$ & $\mathrm{d}(\mathrm{X}) \leftrightarrow \mathrm{d}(\mathrm{Y})$ & $\mathrm{d}(\mathrm{X}) \rightarrow \mathrm{d}(\mathrm{Y})$ & $\mathrm{d}(\mathrm{Y}) \rightarrow \mathrm{d}(\mathrm{X})$ \\
\hline CBOT & U. States & 0.2789 & 0.0726 & 0.6665 \\
\hline LIFFE & U. Kingdom & 0.2674 & 0.1468 & 0.5586 \\
\hline MATIF & France & 0.6760 & 0.0101 & 0.2243 \\
\hline POLAND & Poland & 0.5977 & 0.0092 & 0.4303 \\
\hline
\end{tabular}

Explanations: correlation - the values were provided of the correlation factor, causality - Granger test significance levels were provided. 
Source: Authors' own calculations

The results of the Granger causality test look interesting. Two lags selection were used to compare the results with VAR. It becomes evident that in no case one can talk about causality on the part of economic activity in relation to wheat prices. In France and in Poland, causality from wheat prices to economic activity proves to be statistically significant (with significance levels being $\mathrm{p}=0.0101$ and $\mathrm{p}=0.0092$ respectively). The causality from wheat prices to economic activity for the United States $(\mathrm{p}=0.0726)$ comes close to being recognized as important. It is not significant for the United Kingdom ( $\mathrm{p}=0.1468)$, although in the opposite direction, from economic activity to wheat prices, a greater significance level $(\mathrm{p}=0.5586)$ was obtained. In this respect, one may speak about similarities between these economies.

Despite the fact that a review of the literature demonstrated a bilateral dependency between the condition of the agricultural market and the general economic activity, it proves to be unilateral in the examination presented above. There is an evident causality from the agricultural market (here, wheat prices) to the overall economic activity.

Figure 3 presents output (non-standardized) and standardized increments of wheat prices and the economic activity level. The scale of the variations of wheat prices is definitely higher than the scale of economic activity variations.

The examination of causality, whose results are contained in Table 3, was based on a VAR model with two delays. These models are presented below (cf. Table 4) for each of the economies under examination. The causality tests demonstrate that particular attention is paid to the impact of the past variations in wheat prices on the current economic conditions (Musakwa \& Odhiambo, 2019).

The conclusions based on all the models are similar. It becomes evident that current changes in the economic activity measured by GDP growth are negatively connected with the past increments of wheat prices: negative regression factors with $\mathrm{d}$ (wheat)(-1) variables in all the $\mathrm{d}(\mathrm{GDP})$ models, as well as negative regression factors with d(wheat)(-2) variables in d(DGP) models for the United Kingdom, France and Poland. In the case of Poland, both regression factors with $\mathrm{d}$ (wheat)(-1) and $\mathrm{d}$ (wheat)(-2) are statistically significant and, in the case of the United Kingdom, their significance was not found, even though the impact of the $\mathrm{d}$ (wheat)(-1) variable on $\mathrm{d}(\mathrm{GDP})$ may be considered to be important. 

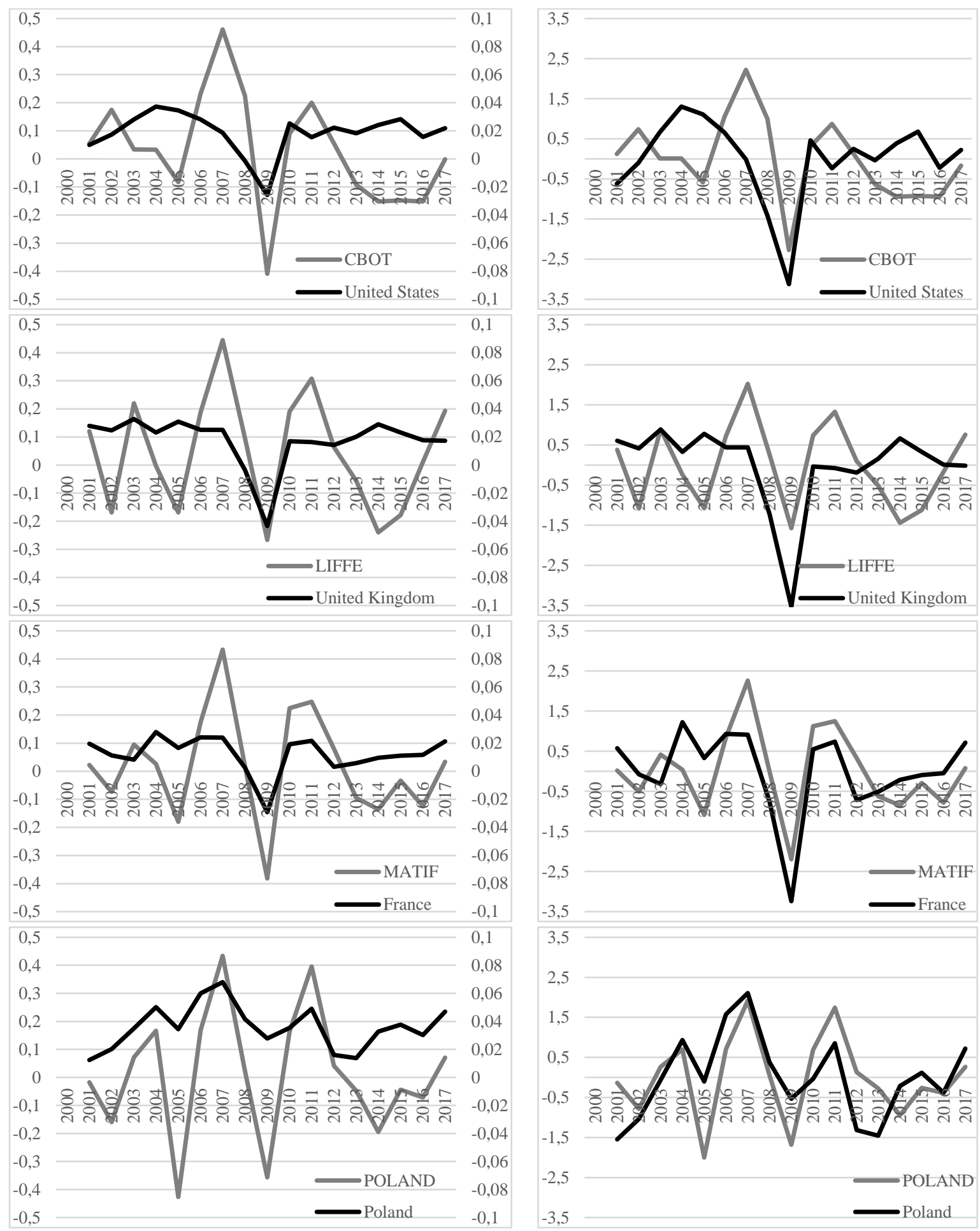

Figure 3. Non-standardized (diagram on the right) and standardized (diagram on the left) relative increments of the quotations of wheat and GDP dynamics.

Source: Authors' own work. 
VAR models for the increments of wheat prices and economic growth

\begin{tabular}{|c|c|c|c|c|c|}
\hline \multicolumn{3}{|c|}{ THE UNITED STATES } & \multicolumn{3}{|c|}{ THE UNITED KINGDOM } \\
\hline & $\mathrm{d}$ (wheat) & $\mathrm{d}(\mathrm{GDP})$ & & $\mathrm{d}$ (wheat) & $\mathrm{d}(\mathrm{GDP})$ \\
\hline \multirow{2}{*}{$\begin{array}{c}\mathrm{d} \text { (wheat) } \\
(-1)\end{array}$} & 0.4311 & -0.0456 & \multirow{2}{*}{$\begin{array}{c}\mathrm{d} \text { (wheat) } \\
(-1)\end{array}$} & 0.2992 & -0.0359 \\
\hline & {$[1.3934]$} & {$[-2.3495]$} & & {$[1.1078]$} & {$[-1.5164]$} \\
\hline \multirow{2}{*}{$\begin{array}{c}\mathrm{d} \text { (wheat) } \\
(-2)\end{array}$} & -0.7183 & 0.0012 & \multirow{2}{*}{$\begin{array}{c}\mathrm{d} \text { (wheat) } \\
(-2)\end{array}$} & -0.6542 & -0.0253 \\
\hline & {$[-1.7430]$} & {$[0.0486]$} & & {$[-2.1796]$} & {$[-0.9624]$} \\
\hline \multirow{2}{*}{$\begin{array}{c}\mathrm{d}(\mathrm{GDP}) \\
(-1)\end{array}$} & -4.8345 & 0.5659 & \multirow{2}{*}{$\begin{array}{c}\mathrm{d}(\text { GDP }) \\
(-1)\end{array}$} & -3.5883 & 0.3785 \\
\hline & {$[-0.8403]$} & {$[1.5657]$} & & {$[-0.9846]$} & {$[1.1821]$} \\
\hline \multirow{2}{*}{$\begin{array}{c}\mathrm{d}(\mathrm{GDP}) \\
(-2)\end{array}$} & 3.7192 & -0.0684 & \multirow{2}{*}{$\begin{array}{c}\mathrm{d}(\text { GDP }) \\
(-2)\end{array}$} & 0.3395 & -0.0776 \\
\hline & [0.7993] & {$[-0.2341]$} & & {$[0.1005]$} & {$[-0.2618]$} \\
\hline \multirow{2}{*}{$\mathrm{C}$} & 0.0614 & 0.0112 & \multirow{2}{*}{$\mathrm{C}$} & 0.1235 & 0.0133 \\
\hline & [0.5636] & [1.6448] & & {$[1.6048]$} & {$[1.9744]$} \\
\hline R-squared & 0.2915 & 0.48728 & R-squared & 0.3888 & 0.4086 \\
\hline \multicolumn{3}{|c|}{ FRANCE } & \multicolumn{3}{|c|}{ POLAND } \\
\hline & $\mathrm{d}$ (wheat) & $\mathrm{d}(\mathrm{GDP})$ & & $\mathrm{d}$ (wheat) & $\mathrm{d}(\mathrm{GDP})$ \\
\hline \multirow{2}{*}{$\begin{array}{c}\mathrm{d} \text { (wheat) } \\
(-1)\end{array}$} & 0.3636 & -0.0111 & \multirow{2}{*}{$\begin{array}{c}\mathrm{d} \text { (wheat) } \\
(-1)\end{array}$} & 0.0054 & -0.0322 \\
\hline & [1.1861] & {$[-0.5923]$} & & [0.0186] & {$[-2.1576]$} \\
\hline \multirow{2}{*}{$\begin{array}{c}\mathrm{d}(\text { wheat }) \\
(-2)\end{array}$} & -1.1143 & -0.0686 & \multirow{2}{*}{$\begin{array}{c}\mathrm{d} \text { (wheat) } \\
(-2)\end{array}$} & -0.9694 & -0.0444 \\
\hline & {$[-3.3819]$} & [-3.3928] & & {$[-2.8783]$} & {$[-2.5944]$} \\
\hline \multirow{2}{*}{$\begin{array}{c}\mathrm{d}(\text { GDP }) \\
(-1)\end{array}$} & -5.9150 & 0.0295 & \multirow{2}{*}{$\begin{array}{c}\mathrm{d}(\mathrm{GDP}) \\
(-1)\end{array}$} & -4.0923 & 0.4201 \\
\hline & {$[-1.2489]$} & {$[0.1016]$} & & {$[-0.6879]$} & {$[1.3884]$} \\
\hline \multirow{2}{*}{$\begin{array}{c}\mathrm{d}(\text { GDP }) \\
(-2)\end{array}$} & 8.0052 & 0.3174 & \multirow{2}{*}{$\begin{array}{c}\mathrm{d}(\mathrm{GDP}) \\
(-2)\end{array}$} & 7.1702 & 0.2161 \\
\hline & [1.7592] & [1.1363] & & [1.3341] & {$[0.7905]$} \\
\hline \multirow{2}{*}{ C } & 0.0228 & 0.0099 & \multirow{2}{*}{$\mathrm{C}$} & -0.0642 & 0.0164 \\
\hline & {$[0.3357]$} & [2.3827] & & {$[-0.3606]$} & [1.8113] \\
\hline R-squared & 0.56228 & 0.6609 & R-squared & 0.5125 & 0.6727 \\
\hline
\end{tabular}

Explanations: t-statistics in [].

Source: Authors' own calculations

Taking into consideration the time shift that occurs in this relationship (from one to two years), it becomes evident that the falls (increases) of wheat prices from before a year (and/or two years) have a positive (negative) effect on changes in the overall economic conditions. This result may be considered as the expected result. From a practical perspective, this means that a growth of agricultural produce is unfavourable to the entire economy. On the one hand, this indeed means higher prices obtained by agricultural producers, yet these higher prices as a rule are the result of a smaller supply. In the meantime, the prices of processed foods are growing, and this weakens overall consumption; furthermore, the production costs are growing of products based on agricultural raw materials. Finally, this situation may have the negative impact on the demand for industrial products.

It is evident based on the diagram of the impulse response function (Figure 4) that there is a relatively strong similarity between the individual economies in the reaction of the increments of wheat prices (the diagram on the left) and GDP increments (the diagram on the right) to their delayed values. It is evident that in the case of wheat price increments, their delayed values have the relatively strong impact on them, while delayed GDP values have the substantially smaller impact on them. The impulses are lost for about 
three years. From the perspective of the present paper, the poor reaction of wheat price increments on GPD variations is important here.
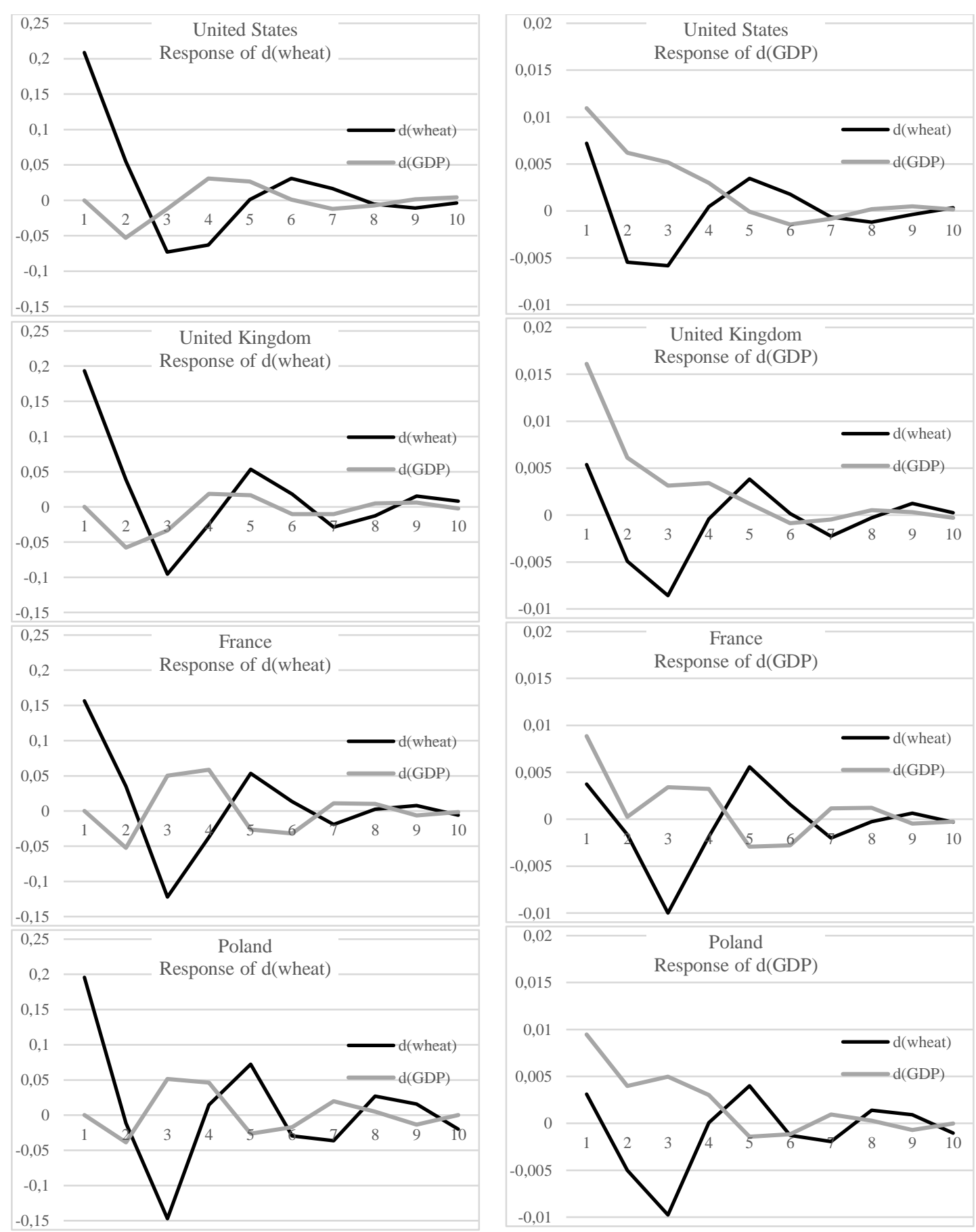

Figure 4. Function of response to the impulse of the quantity of one standard deviation: reaction of wheat price increments and GDP increments to their delayed values.

Source: Authors' own work.

The situation is different in the case of the reaction of GDP increments for the impulse from delayed wheat price increments and delayed GDP increments. Here, a stronger reaction is initially observed to 
delayed GDP increments than to delayed wheat price increments. The reaction of GDP increments on an impulse for wheat prices becomes reverse to the direction of wheat price variations in the second and third years starting from the occurrence of the impulse; regarding the force, it is even stronger then the reaction to delayed GDP increments. This situation is a consequence of the regression factors obtained in the models presented in Table 4, and it shows a particular significance of agricultural produce prices in the formation of the overall economic conditions.

\section{DISCUSSION OF RESULTS}

Though, there is no agreement among authors as to the role of agriculture in fostering economic growth, as some scholars highlighted that agriculture development was essential for overall economic transformation of a country (Johnston, 1970; Remeikiene et al., 2018), and other scholars noted that economic growth of industrialized countries was just linked to the development of the industrial and service sectors (Martin \& Warr, 1990), this study provides some insights into this debate.

The results of the study indicated that wheat prices had an inhibiting effect on the future GDP dynamics, while decreasing wheat prices had a stimulating effect on the future GDP dynamics. This can be explained by the lag that occurs between harvest, processed production and industrial production based on agricultural raw materials. Higher wheat prices weaken consumption, which is translated into an economic slowdown; whereas decreasing prices of agricultural produce may strengthen the consumption. The results of this paper are in line with other studies indicating the importance of agriculture to GDP, as well as the effect of the prices of agricultural raw materials for the entire economy (Drelich-Skulska \& Jankowiak, 2019; Kozlovskyi et al., 2018; Proshchalykina et al., 2019; Mashokhida et al., 2018).

The results of this study also advocate the support for agriculture provided by the Common Agricultural Policy aiming to support farmers and improve agricultural productivity by ensuring a stable and affordable food supply (Pietrzak, 2019; Kotykova \& Babych, 2019; Stanciu et al., 2019; Balezentis \& Novickyte, 2018); protecting the livelihood of farmers in the European Union (Marikina, 2018; Nagyová et al., 2016; Mostenska \& Bilan, 2015).

Great Britain's agriculture is one of the most modern in the world. It is also very diverse, but mediumsized farms dominate. The current political situation can cause significant changes in the structure of exports and imports. And too date, cereals and cereal products, dairy products, meat, fish and fruit products are of the greatest importance in agricultural exports in Great Britain. The country is at the forefront in the production of meat, milk and wool. The main trading partners are: EU countries (especially Germany, France, the Netherlands, Belgium) and the USA, and China. It should be assumed that due to the fact that the United Kingdom is leaving the European Union, then some temporary export difficulties may arise. Unfortunately, the future condition of agriculture will largely depend on political rather than economic decisions. The biggest problem on trade may be the appearance of non-tariff barriers - limits for certain groups of goods, as well as the need to obtain special certificates before placing goods in the market. This will certainly introduce some reshuffles in the UK and EU markets as well as temporary instability, which may have negative short-term consequences for economic growth. Until now, in the long-term, economies have always dealt with such problems, and this will probably be the case now.

\section{CONCLUSION}

The research presented herein points to a crucial importance of the role of agricultural produce prices in the levels of the Gross Domestic Product. This, indeed, is not a straightforward connection as agriculture constitutes one of many economic sectors; furthermore, the contribution of agriculture to GDP has been evidently decreasing over the past years. Considering the decreasing contribution of agriculture to GDP 
and, at the same time, the great importance of the prices of agricultural raw materials for the entire economy, one should take a cautious approach to the deagrarianization concept. Agriculture should be used as part of the overall sustainable development of the economy.

The research presented herein was limited to one agricultural produce, i.e. the wheat. This produce can be considered to be a representative of the total of agricultural produce. Wheat is grown in all the countries covered by the research and, in all of them, it is one of the most important cereals. Therefore, the conclusions based on the observations of the relationship between wheat prices and the overall economic activity measured with GDP may be generalized as being a relationship between the agricultural sector and GDP.

In accordance with theory and the research conducted so far, one could expect a bilateral dependency between the condition of the agricultural market and general economic conditions, whereas the research conducted herein explicitly points to an asymmetry in this relationship and leads one to consider this dependency as unilateral. It becomes evident that the general economic condition is under a substantial influence of agricultural produce prices. The nature of this dependency is fairly complex as it seems apparent that a higher GDP growth corresponds to growing wheat prices (an apparent correlation). This result, however, did not disclose any influence of any delayed change. Only when this fact was taken into consideration, the real picture of the dependency between GDP growth and the increments of wheat prices was shown. It becomes evident that growing wheat prices have an inhibiting effect on the future GDP dynamics, while decreasing wheat prices have a stimulating effect on the future GDP dynamics. This can be explained by the lag that occurs between harvest, processed production and industrial production based on agricultural raw materials. Higher wheat prices weaken consumption, which translates into an economic slowdown; whereas decreasing prices of agricultural produce may strengthen consumption.

This view of the dependency in question would suggest that efforts need being aimed at as low agricultural produce prices as possible. This is an expected state from a short-term perspective. From a longterm perspective, however, many problems might arise; first of all, this means lower revenues of a substantial part of society dealing with the production of unprocessed agricultural produce, which will lower their investment and consumption related potential. Therefore, striving for the lowest prices is in contradiction with the concept of sustainable development. The uses of financial support might be a solution here, yet this has a negative effect on the government budget.

Taking the economic practice into consideration, especially that of the European Union, one may state that the policy used in relation to the agricultural market is a policy that is favourable to the stabilization of the incomes of agricultural producers and a sustainable growth. The direct payments system is to guarantee to farmers an adequate level of income, even though it does not stabilize prices. Furthermore, numerous additional programmes are in use, especially those that support investment activities. The objective of the system is to guarantee an adequate level of income through an adequate level of the prices obtained through the system of area payments. In a free market economy, demanding a guarantee of prices seems to be a little anachronic, yet it needs to be noted that the food system performs not only purely economic functions in the economy, but its primary goal is to satisfy the human's vital needs.

The research presented in the article and the observations resulting therefrom, of course, result from the analysis of only four countries, but it should be emphasized that three of the considered are the strength of the global economy. The very fact of a significant relation of trends observed on the example of Poland to the other three may indicate that the observed trends can actually take place. Yes, perhaps, any observations may be slightly corrected in the case of an increased research group, but this does not mean that the observed trends are not correct. One should remember about significant interdependencies on global markets, especially on stock markets. 
However, it may be interesting to relate the results of the research to the Chinese economy, which the authors plan to do in subsequent studies. Perhaps the inferences made then will more closely reflect the real trends of the global agricultural market.

\section{REFERENCES}

Algieri, B. (2014). A roller coaster ride: an empirical investigation of the main drivers of the international wheat price. Agricultural Economics, 45(4), 459-475. https:/ / doi.org/10.1111/agec.12099.

Balezentis, T., \& Novickyte, L. (2018). Are Lithuanian family farms profitable and financially sustainable? Evidence using DuPont model, sustainable growth paradigm and index decomposition analysis. Transformations in Business \& Economics, 17(1) (43), 237-254.

Bilan, Y., Lyeonov, S., Stoyanets, N., \& Vysochyna, A. (2018). The impact of environmental determinants of sustainable agriculture on country food security. International Journal of Environmental Technology and Management, 21(5-6), 289-305.

Borensztein, E., \& Reinhart, C.M. (1994). The macroeconomic determinants of commodity prices. IMF Staff Pap., $41(2), 236-261$.

Clark, C.A. (1940). The conditions of economic progress. Macmillan, London.

Drelich-Skulska, B., \& Jankowiak, A.H. (2019). The meaning of cluster policy in the process of integration between the European Union member states. Transformations in Business \& Economics, 18(2)B (47B), 783-801.

Enders, W. (2004). Applied Econometric Time Series. John Wiley \& Sons, New York.

Engle, R.F., \& Granger, C.W.J. (1987). Cointegration and error correction representation, estimation and testing. Econometrica, 55, 251-257.

Fisher, A.G. (1935). The clash of progress and security. Macmillan, London.

Gallego-Bono, J.R., \& Chaves-Avila, R. (2019). How to boost clusters and regional change through cooperative social innovation. Economic Research - Ekonomska Istrą̌ivanja, http://doi.org/10.1080/1331677X.2019.1696694

Gilbert, C. L. (2010). How to Understand High Food Prices. Journal of Agricultural Economics, 61, 398-425.

GOS. (2011). Foresight. The Future of Food and Farming: Challenges and Choices for Global Sustainability. Final Project Report. London: The Government Office for Science.

Granger, C. W. J. (1969). Investigating Causal Relations by Econometric Models and Cross-spectral Methods. Econometrica, 37(3), 24-36.

Guth, M., \& Smędzik-Ambroży, K. (2019). Economic resources versus the efficiency of different types of agricultural production in regions of the European union. Economic Research - Ekonomska Istraživanja, 32(1), 1-16, http://doi.org/10.1080/1331677X.2019.1585270

Huo, D., Chen, Y., Hung, K., Song, Z., Guan, J., \& Ji, An. (2019). Diamond model and the export competitiveness of the agriculture industry from emerging markets: an exploratory vision based on a spatial effect study using a genetic algorithm. Economic Research - Ekonomska Istrą̌ivanja, 32(1), 1-17. http://doi.org/10.1080/1331677X.2019.1679212.

Ivashkiv, I., Kupalova, H., Goncharenko, N., Khrutba, Y., \& Vovk, I. (2019). Optimization of commodity flows: The case of bakery enterprises of Ukraine. Montenegrin Journal of Economics, 15(3), 205-216. https://doi.org/10.14254/1800-5845/2019.15-3.15

Johnston, B.F. (1970). Association Agriculture and Structural Transformation in Developing Countries: A Survey of Research. Journal of Economic Literature, 8(2), 369-404.

Keatinge, F. (2015). Influential factors in the econometric modeling of the price of wheat in the United States of America. Agricultural Sciences, 6, 758-771.

Kocisova, K., Gavurova, B., \& Kotaskova, A.A (2018). Slack-based measure of agricultural efficiency in the European Union countries. Journal of International Studies, 11(1), 189-200. doi:10.14254/2071-8330.2018/11-1/14

Kotykova, O., \& Babych, M. (2019). Limitations in availability of food in Ukraine as a result of loss and waste. Oeconomia Copernicana, 10(1), 153-172. doi: 10.24136/oc.2019.008. 
Kozlovskyi, S., Mazur, H., Vdovenko, N., Shepel, T., \& Kozlovskyi, V. (2018). Modeling and Forecasting the Level of State Stimulation of Agricultural Production in Ukraine Based on the Theory of Fuzzy Logic. Montenegrin Journal of Economics, 14(3), 37-54.

Lagi, M., Bar-Yam, Y., \& Bertrand, K.Z. (2011). The Food Crises: A Quantitative Model of Food Prices Including Speculators and Ethanol Conversion. Cambridge: New England Complex Systems Institute.

Lewis, W. A. (1954). Economic development with unlimited supplies of labour. The Manchester School, 22, 139-191. doi:10.1111/j.1467-9957.1954.tb00021.x

Marikina, M. (2018). The impact of ecological regulations and management on national competitiveness in the Balkan States. Journal of Competitiveness, 10(4), 120-135.

Martin, W. \& Warr, P.G. (1990). The Declining economic importance of agriculture. National Centre for Development Studies and Department of Economies, Research School of Pacific Studies, Australian National University.

Mashokhida, A., Khabibovich, A. A., Pálka, P., \& Shakhlo, R. (2018). The competitiveness and sustainable economic development of Tajikistan regions. Journal of Competitiveness, 10(1), 73-88.

Morkūnas, M., Volkov, A., \& Galnaityte, A. (2019). Government or invisible hand? Who is in charge of retail food prices? Evidence from the Baltics. Journal of International Studies, 12(3), 147-157. doi:10.14254/2071$8330.2019 / 12-3 / 12$

Mostenska, T. \& Bilan, Y. (2015) Sustainable development through enhanced social responsibility. Journal of Security and Sustainability Issues, 4(3), 536-551. doi: http://dx.doi.org/10.9770/jssi.2015.4.3(4)S

Musakwa, M. T., \& Odhiambo, N.M. (2019). FDI and poverty reduction in Botswana: A multivariate causality test. Economics and Sociology, 12(3), 54-66. doi:10.14254/2071-789X.2019/12-3/4.

Nagyová, L., Holienčinová, M., Rovný, P., Dobák, D., \& Bilan, Y. (2016). Economic sustainability of primary agricultural production: the Slovak Republic in the EU context. Journal of Security and Sustainability Issues, 6(2), 259-274. doi: http://dx.doi.org/10.9770/jssi.2016.6.2(6)

Phillips, P. C. B. (1986). Understanding Spurious Regressions in Econometrics. Journal of Econometrics, 33(3), 311-340.

Pietrzak, M. B. (2019). Modifiable Areal Unit Problem: the issue of determining the relationship between microparameters and a macroparameter. Oeconomia Copernicana, 10(3), 393-417. doi: 10.24136/oc.2019.019

Prakash, A. (2011). Safeguarding Food Security in Volatile Global Markets. Food and agriculture organization of the United Nations, Rome.

Proshchalykina, A., Kyryliuk, E., \& Kyryliuk, I. (2019). Prerequisites for the development and prospects of organic agricultural products market, Entrepreneurship and Sustainability Issues, 6(3), 1107-1117. http://doi.org/10.9770/jesi.2019.6.3(18)

Pryor, S., \& Holt, T. (1999). Agribusiness as an engine of growth in developing countries. U.S. Agency for International Development, Washington, DC.

Remeikiene, R., Gaspareniene, L., \& Volkov, A. (2018). Evaluation of the influence of the export in agricultural products on the Baltic states economic growth. Montenegrin Journal of Economics, 14(3), 83-94.

Rezitis, A.N., \& Sassi, M. (2013). Commodity food prices: review and empirics. Economics Research International, Article ID 694507. doi: 10.1155/2013/694507

Romer, D. (1996). Advanced Macroeconomics. McGraw-Hill, New York.

Rostow, W.W. (1960). The Stages of Economic Growth: A Non-Communist Manifesto; Cambridge at the University Press, London.

Ruttan, V.W. (1965). Growth stage theories and agricultural development policy. Australian Journal of Agricultural Economics, 9, 17-32.

Sánchez García, J.L., Beiro Pérez, I., \& Díez Sanz, J.M. (2019). Hunger and sustainability. Economic Research - Ekonomska Istrą̌ivanja, 32(1), 850-875. http://doi.org/10.1080/1331677X.2019.1583588.

Sánchez-López, C., Aceytuno, M.T., \& de Paz-Báñez, M.A. (2019). Inequality and globalisation: Analysis of European countries. Economics and Sociology, 12(4), 84-100. doi:10.14254/2071-789X.2019/12-4/5

Sims, C.A. (1980). Macroeconomics and reality. Econometrica, 48(1), 1-48.

Stanciu, S., Virlanuta, F.O., Dinu, V., Zungun, D., \& Marian, V. (2019). The Perception of the Social Economy by Agricultural Producers in the North-East Development Region of Romania. Transformations in Business \& Economics, 18(2B) (47B), 879-899. 
Tittonell, P. (2014). Ecological intensification of agriculture - Sustainable by nature. Environmental Sustainability, 8, 5361. doi:10.1016/j.cosust.2014.08.006

Toda, H.Y., \& Phillips, P.C.B. (1993). Vector autoregressions and causality. Econometrica, 61(6), 1367-1393. doi:10.2307/2951647

Todaro, M.P. \& Smith, S. (2011). Economic Development. Prentice Hall; 11th edition.

Trostle, R. (2008). Global Agricultural Supply and Demand: Factors Contributing to the Recent Increase in Food Commodity Prices. A Report from the Economic Research Service, Washington: United States Department of Agriculture.

Tsakok, I., \& Gardner B. (2007). Agriculture in economic development: primary engine of growth or chicken and egg?. American Journal of Agricultural Economics, 89(5), 1145-1151.

Udemezue, J.C., \& Osegbue, E.G. (2018). Theories and Models of Agricultural Development. Annals of Reviews \& Research, 1(5), 134-137.

UNEP. (2011). Towards a Green Economy: Pathways to Sustainable Development and Poverty Eradication - A Synthesis for Policy Makers. www.unep.org/greeneconomy.

Wiggins, S., Keats, S., \& Compton, J. (2010). What caused the food price spike of 2007/08?. Lesson for World Cereals Markets, Food Prices Project Report, London: Overseas Development Institute. 